\title{
Late Holocene vegetation history in Harghita Mountains (Romania)
}

\author{
Andrei-Marian PANAIT ${ }^{1} *$ and loan TANTĂU ${ }^{1}$ \\ ${ }^{1}$ Babeş-Bolyai University, Department of Geology, 1 Kogălniceanu Street, 400084 Cluj-Napoca, \\ Romania \\ * Correspondence to: Andrei-Marian Panait. E-mail: pnt_andrei@yahoo.com \\ (C2012 University of Suceava and GeoConcept. All rights reserved \\ doi: 10.4316/GEOREVIEW.2012.21.1.58
}

\section{GEOREVIEW}

\section{Article history}

Received: September 2012

Received in revised form: Oct. 2012

Accepted: November 2012

Available online: January 2013

\begin{abstract}
We present here the pollen analysis of two sequences originating from two peat bogs from Harghita Mountains. The vegetation record, which is supported by five ${ }^{14} \mathrm{C}$ dates, starts in the Subboreal (age) with the Carpinus optimum. During the Subatlantic (age) the vegetation is dominated by Fagus. Indications of human impact (especially agricultural activities) in the region occur at the beginning of the Subboreal (at ca. 4200 years BP).
\end{abstract}

KEY WORDS: vegetation history, forest dynamics, pollen analysis, Late Holocene, Harghita Mountains

\section{Introduction}

The Late Holocene represents the last period from geologic history and includes the Subboreal period which is characterized by the optimum of Carpinus betulus and the Subatlantic period, which is dominated by beech (Fagus sylvatica) forests. During this period of the Holocene which started about 5000 years BP several climatic oscillations were identified in Romania: the 'Medieval warm period' and the 'Little Ice Age' which had a strong influence on flora and fauna (Feurdean et al., 2009, 2011; Geanta et al., 2012).

In Harghita Mountains are few studies about the vegetation history. First simplified palynological analysis in this zone was made by Szalai (1943) that published a sequence from Luci with $540 \mathrm{~cm}$ in depth, and the bottom attributed to the Preboreal.

After few years, palynological and botanical investigations in this zone were made by Pop (1962) that show a detailed description of the vegetation from Mohoş and Luci. Pop (1960) also showed in his work the presence of a glacial relict Betula nana at Luci site.

In 1967 Pop and Diaconeasa published pollen analysis of two sequences from Mohoş peat bog that shows the vegetation history in this zone, but they don't mention Fraxinus in their pollen diagram. After almost 40 years Tanţău $(2003,2006)$ publish a new set of pollen diagrams, from Luci and Mohoş, which are more complex and are supported by ${ }^{14} \mathrm{C}$ dates. 
Also Magyari et al. (2006) publish a study about Holocene palaeohydrology and environmental history in the South Harghita Mountains which include a pollen analysis in sediments of Saint-Ana Lake.

Two sites are compared in this study: Mohoş and Luci peat bogs. The aim of this study is to reconstruct the Late Holocene vegetation history in Harghita Mountains, by comparing the pollen analysis realized in the two sites (Tanţău 2003, 2006, Tanţău et al., 2003). Both peat bogs are natural reservations for protection of relict plant like: Empetrum nigrum, Drosera rotundifolia, $D$. obovata, Andromeda polifolia.

\section{Study area}

The studied peat bogs occupy the bottom of two volcanic craters from the Harghita Mountains (Fig. 1). Harghita Mountains are the last massif of the Neogene eruptive chain Calimani-GurghiuHarghita. The altitude of bogs is $1079 \mathrm{~m}$ at Luci and $1050 \mathrm{~m}$ at Mohoş. Both of them are locally composed of Sphagnum peat. The local vegetation of these sites is similar, with forest of red pine (Pinus sylvestris), downy birch (Betula pubescens), black alder (Alnus glutinosa), and different species of willow (Salix).

Mohoş is located in the northeast of Saint Ana Lake, in the crater of the twin massive Puciosu (Ciomatu). The local vegetation type is assigned to the 'Vaccinio uliginosi - Pinetum silvestri' plant community, while the specific vegetation stage for this altitude (middle mountainous) is typically characterized by the 'Symphyto cordati-Fagetum' plant community (Coldea, 1991). From herbaceous plants specific on peat bogs the most abundant are: Empetrum nigrum, Vaccinium vitis idaea, Vaccinium oxyccocos, and Andromeda polifolia.

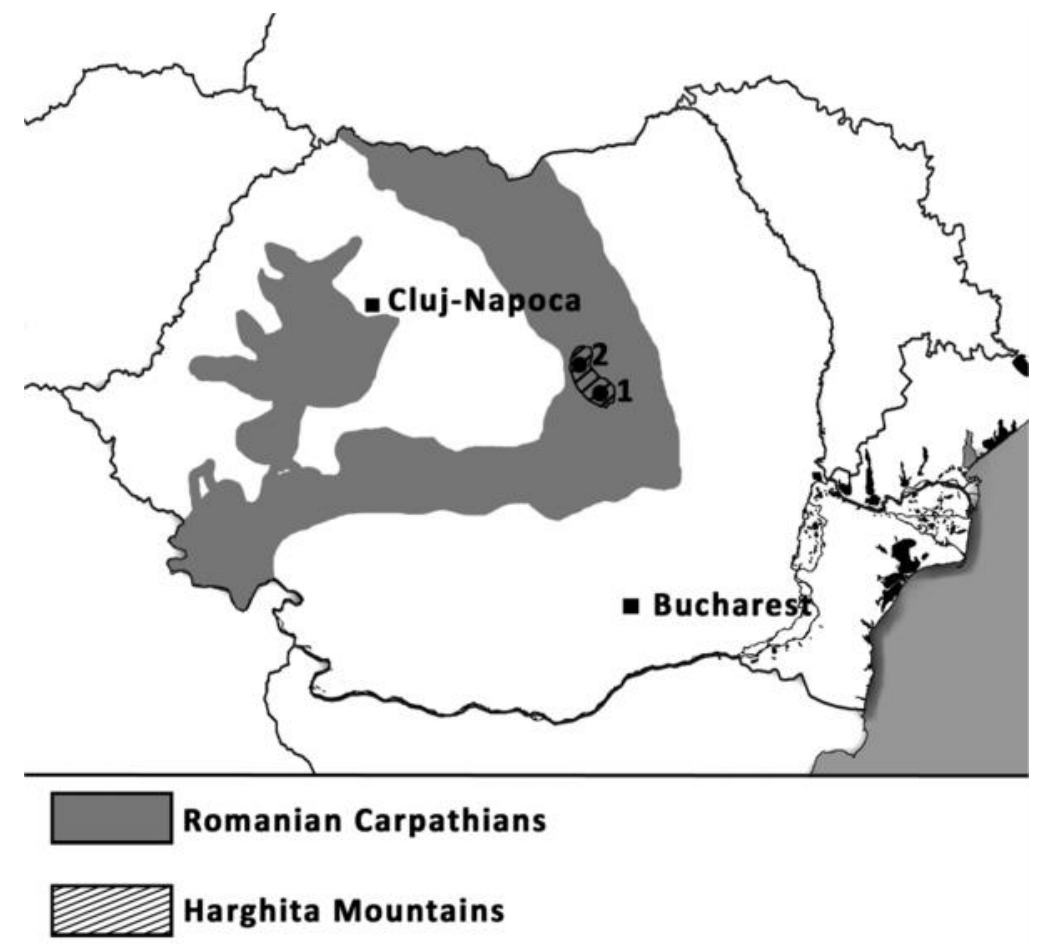

Figure 1. Romania map with the studied sites: 1 - Mohoş, 2 - Luci. 
Luci peat bog is formed also by accumulation of peat into a crater lake. The peat is manly formed by Sphagnum spp. Other species as Andromeda polifolia, Drossera rotundifolia and Betula nana are present. At the periphery of the bog in north and in south, vegetation is dominated by an association Sphagno - Caricetum rostratae Steffen, with Viola epipsila, relict species more abundant in the northern part of the peat bog. At the center of the bog, the association is Eriophoro vaginati - Sphagnetum recurvi Huek. In the middle and upper bog there is also the association Vaccinio - Pinetum sylvestris Klest with the sub-association Betuletosum nanae (Coldea and Plămadă, 1989; Coldea et al., 1997).

The region is characterized by a temperate-mountainous climate with an annual precipitation level above 1,000 $\mathrm{mm}$. Precipitation reaches a maximum during summer and a minimum during winter. The mean annual temperature is $3^{\circ} \mathrm{C}$ and the mean summer temperature is $15^{\circ} \mathrm{C}$.

\section{Methodology}

The pollen analyses of two sequences located in Harghita Mountains were compared (Tanţău et al., 2003; Tanţău, 2006). Only the upper part of the pollen diagrams (the Subboreal and Subatlantic periods) was used for this study. The chronology was established by radiocarbon data at the Laboratory of the Radiocarbon in Poznan (Poland).

\section{Results}

\subsection{Chronology}

Five $\mathrm{AMS}{ }^{14} \mathrm{C}$ ages were used to obtain the chronology of the two sequences: three ages for Mohoş and two ages for Luci (Figs. 3-4) (Tanţău et al., 2006). The transition SubborealSubatlantic, which marked the beginning of the Fagus optimum, is well dated at Mohoş (2910 \pm 90 years BP) than at Luci (only $2460 \pm 40$ years BP), where the transition is probably affected by a hiatus of sedimentation (Figs. 3-4).

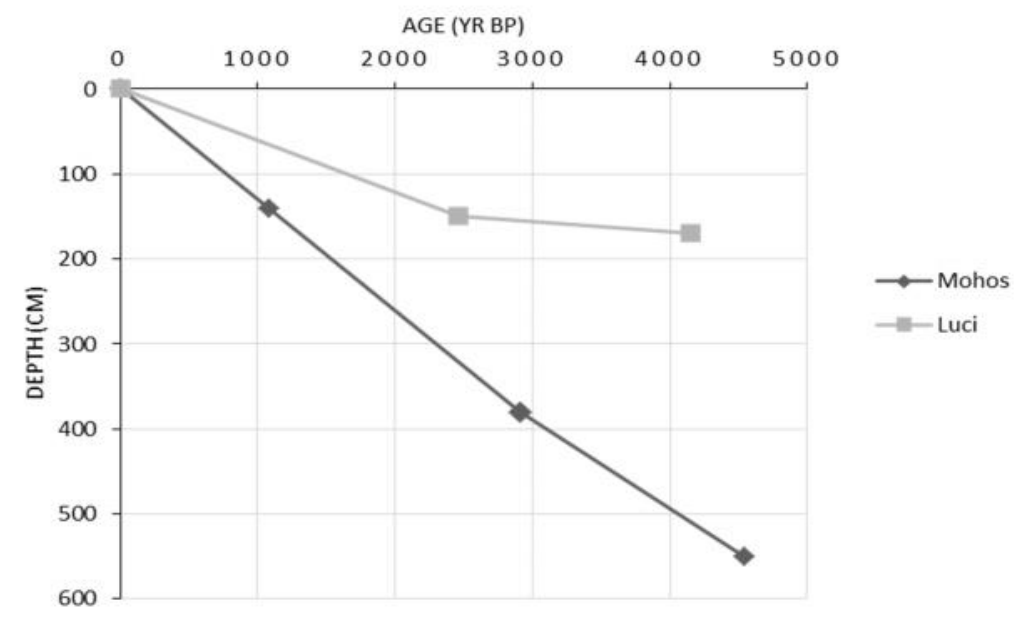

Figure 2. Age-depth model for Mohoş and Luci sequences. 
The age-depth model was constructed based on linear interpolation of $\mathrm{AMS}{ }^{14} \mathrm{C}$ ages (Fig. 2). Based on age-depth model there are some differences between Luci and Mohoş peat bogs, as the accumulation rates are concerned, being more uniform for the latter one. This diagram shows a higher sedimentation rate for the Mohoş peat bog $(0.12 \mathrm{~cm} / \mathrm{year}$ ) than for Luci (only $0.05 \mathrm{~cm} /$ year).

\subsection{Vegetation history}

Four regional pollen zones are distinguished: the sequence Mohoş recorded all four zones while Luci includes only three local pollen zones (Figs. 3-4). Based on the main changes in the pollen percentages in these local zones the following points may be made:

口 LPAZ 1 (ca. 4500-3500 years BP, depth: 550-430 cm at Mohoş): This zone corresponds to a maximum expansion of Carpinus betulus. The beginning of this zone is dated to about 4550 BP. The end of this Carpinus optimum expansion is dated between $2460 \pm 170$ years BP at Luci and 2,910 \pm 90 years BP at Mohoş.

口 LPAZ 2 (ca. 3500-2900 years BP, depth: 430-380 cm): In this zone, which is present only in Mohoş sequence, Fagus sylvatica replaces Carpinus betulus. Picea abies was also present in the studied zone. Percentages of Ulmus and Fraxinus decrease.

L LPAZ 3 (ca. 2900 years BP - historical times, depth: 380-50 cm): This zone is marked by the absolute dominance of Fagus, with values over 50\%. At that time, Fagus extended over the whole periphery of the craters, gradually supplanting Picea, which could probably maintain itself on the summits only. Abies alba, represented by sporadic pollen occurrences, plays a modest role during the Fagus optimum. Herbs are not abundant in this zone, but human activity is attested by regular records of cereal pollen (Secale) and Plantago lanceolata.

- LPAZ 4 (modern times): In this modern zone, evidence is found for a peak in agricultural activities. Cereals pollen is present in all the pollen spectra of this zone. Fagus percentages fall abruptly to values below $20 \%$. The increase in Pinus pollen percentages (modest at Mohoş) is due to an anthropogenic opening of forest environments.

\section{Vegetation history and human impact}

The pollen records illustrate the vegetation history and human impact during the SubborealSubatlantic periods (Figs. 3-4). The results are then correlated with the available data from other investigations in the Romanian Carpathians to give a general picture of the Late Holocene forest development in Romania. The start of Late Holocene is marked in Romania by the maximum expansion of Carpinus betulus (Tanţău, 2006).

\subsection{Subboreal (ca. 4500 - 2900 years BP)}

The bottom of the sequence is dated at $4550 \pm 100$ years BP in Mohos and at $4150 \pm 35$ years BP in Luci, and begins with the Carpinus betulus maximum expansion. At that time vegetation around the craters was a $C$. betulus forest. Picea was probably present at the summits. Corylus avellana, Betula, Quercus, Picea abies and Alnus were also present in the region.

Herbaceous plants are few, but agricultural activities are confirmed by the first occurrences of cereals and Plantago lanceolata at ca. 4200 years BP. 
The maximum expansion for Carpinus betulus was recorded in some other diagrams from Romanian Carpathians starting at 4800-5200 years BP (Farcas et al., 1999; Björkman et al., 2003; Bodnariuc et al., 2002; Tanţău et al., 2006, 2009, 2011). This optimum of $C$. betulus ends at about 3000 years BP with the Fagus sylvatica expansion (Fig. 3).

\subsection{Subatlantic (ca. 2900 years BP - present)}

The start of Subatlantic is marked by high percentages of Fagus sylvatica pollen, which is recorded earlier at Mohoş (ca. 3000 years BP) than at Luci (ca. 2500 years BP), where the transition is probably affected by a hiatus of sedimentation. During this period the pollen spectra are dominated by $F$. sylvatica, whose frequencies reach $50 \%$, indicating its dominance in the local forests. It shares the territory with Picea, which probably occupies mainly the ridges.

The maximum expansion for Fagus sylvatica was recorded in some other diagrams from Romanian Carpathians starting at 2500-3500 years BP (Farcas et al., 1999; Bodnariuc et al., 2002; Feurdean and Willis 2008; Feurdean et al., 2009; Tanţău et al., 2009, 2011).

The moderate percentages of Carpinus betulus indicate the presence of this tree in the region. Abies alba pollen is recorded with fairly regular appearances and Juglans is also present in the area. First occurrences of Juglans are recorded at about 2000 years BP at Luci and only at about 600 years BP at Mohoş (Figs. 3-4). Other trees (Betula, Quercus, Corylus avellana, Picea abies and Alnus) are present in the region, but they display small percentages and fluctuating values, due to the episodic forest clearance.

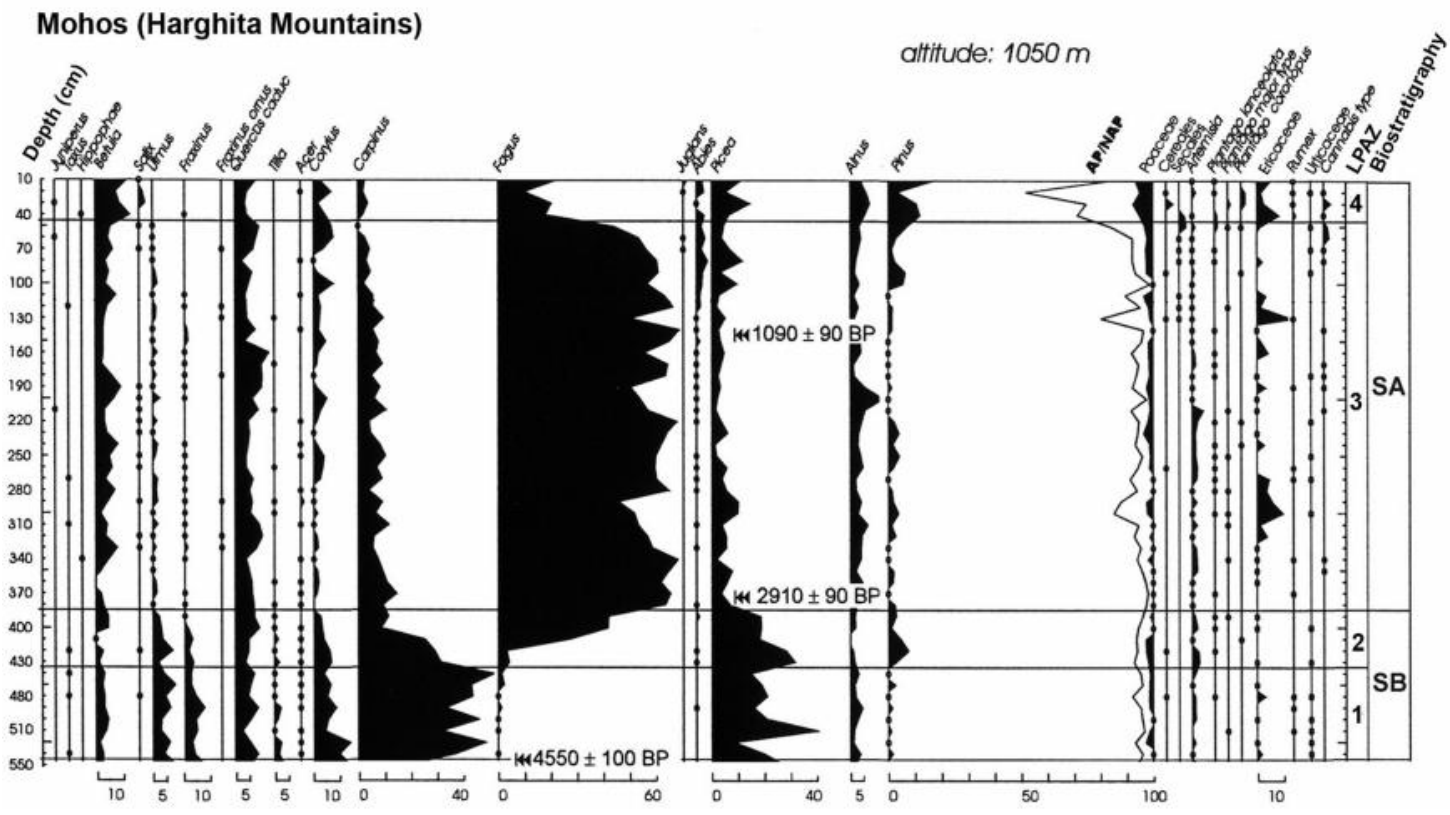

Figure 3. Simplified pollen diagram from Mohoş (after Tanţău et al., 2003, modified). 


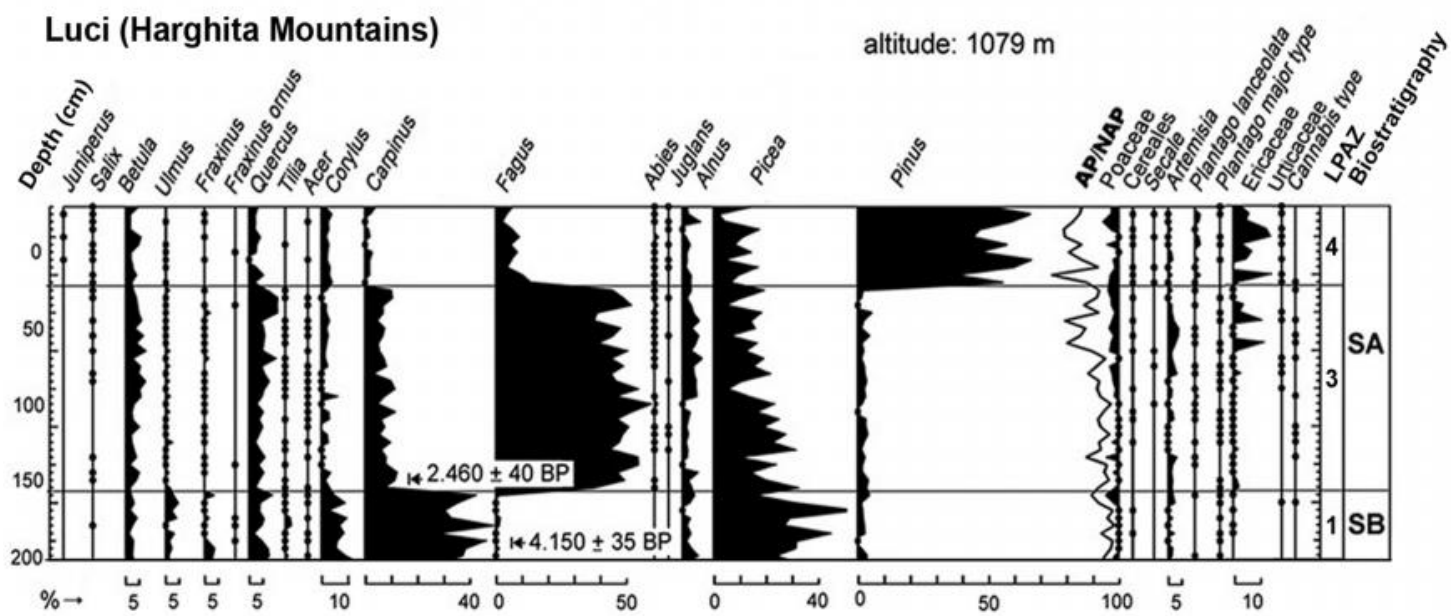

Figure 4. Simplified pollen diagram from Luci (after Tanţău, 2006, modified).

Human activity (especially agriculture and grazing) during this period is evidenced by the regular presence of the cereals pollen, Secale and Plantago lanceolata.

Towards the end of the interval (during the last centuries) we note the increase in pollen of anthropogenic indicators and this is associated to a change in the natural vegetation composition. The proportion of Fagus collapse suddenly and Pinus takes his place. The pollen of this pioneer opportunistic taxon reached percentages as high as 60\%). Carpinus also records a decline at the same time with Fagus, maybe due to the deforestation.

Archaeological evidences about human occupation were found near the Mohoş crater: traces of Boian culture (middle Neolithic) dated to 5500-6000 years BP were found at Brăduţ Turia (Székely, 1998); pottery of Cucuteni culture (5300-5600 years BP) were found at Malnaş-Băi (Laszlo, 1997), and settlements confined to Bronze Age (3500-4000 years BP) were found at Albiş and Peteni (Székely, 1980).

\section{Conclusions}

During the Late Holocene, the vegetation of Harghita Mountains was mainly dominated by Carpinus forests between 4500 and 3000 years BP and by Fagus forests between 3000 BP and about 200 years BP.

In modern times a strong regression of Fagus in the favor of Pinus took place due to the human impact. Also pollen from Picea, Alnus, Betula and Quercus is quite significant.

Carpinus records a decline at the same time with Fagus, sign of high human activity, suggesting deforestation.

Herbaceous plants are few, but agricultural activities are confirmed by presence of cereals since the Subboreal period. Cereals are recorded during the Carpinus optimum and throughout the Fagus phase, and they become more regular with the appearance of Plantago lanceolata, at ca. 2000 years BP.

During the last centuries the Poaceae progresses, sign of expansion of grasslands. 


\section{References}

Björkman S., Feurdean A., Wohlfarth B. 2003. Late glacial and Holocene forest dynamics at Steregoiu in the Gutâiului Mountains, Northwest Romania. Review of Palaeobotany \& Palynology 124: 79-111.

Bodnariuc A., Bouchette A., Dedoubat J.J., Otto T., Fontugne M., Jalut G., 2002. Holocene vegetational history of the Apuseni Mountains, central Romania. Quaternary Sciences Reviews 21: 1465-1488.

Coldea Gh. 1991. Prodrome des associations vegetales des Carpates du sud-est (Carpates roumaines). Documents Phytosociologiques 13: 539. Camerino.

Coldea Gh. 1997. Classe Scheuchzerio-Caricetea nigrae, Classe Oxycocco-Sphagnetea, in Coldea Gh., "Les associations végétales de Roumanie", Volume 1, "Les associations herbacées naturelles": 125-139. Presses Univ. de Cluj. Cluj-Napoca.

Coldea, Gh., Plămadă, E. 1989. Vegetaţia mlaştinilor oligotrofe din Carpaţii Româneşti (Cl. Oxycocco-Sphagnetea Br.-Bl. et Tx. 43). Contributii Botanice: 37-43.

Fărcaş, S., Beaulieu, J.L. de, Reille, M., Coldea, G., Diaconeasa, B., Goeury, C., Goslar, T., Jull, T. 1999. First $14 \mathrm{C}$ dating of Late Glacial and Holocene pollen sequences from Romanian Carpathes. Comptes Rendus de l'Académie des Sciences de Paris 322: 799-807.

Feurdean, A., Willis, K.J. 2008. Long-term variability of Abies alba (Mill.) populations in the NW Romanian forests - implications for its conservation management. Diversity and Distribution 14: 1004-1017.

Feurdean A., Willis K.J., Astalos C. 2009. Legacy of the past land use changes and management on the 'natural' upland forests composition in the Apuseni Natural Park, Romania. The Holocene 19: 967-981.

Feurdean A., Perşoiu A., Pazdur A., Onac B.P. 2011. Evaluating the palaeoecological potential of pollen recovered from ice in caves: A case study from Scărişoara Ice Cave, Romania. Review of Palaeobotany and Palynology 165: 1-10.

Geantă A., Tanţău I., Tămaş T., Johnston V. 2012. Palaeoenvironmental information from the palynology of an 800 years old bat guano deposit in NW Transylvania (Romania). Review of Palaeobotany and Palynology 174: 57-66.

Laszlo A. 1997. Malnas Bai, Cronica cercetarilor arheologice 1983-1992. The National Commission for Archaeology, Bucharest, pp. 52 - 53.

Magyari E.K., Buczkó G., Jakab G., Braun M., Szántó Z., Molnár M., Pál Z., Karátson D. 2006. Holocene palaeohydrology and environmental history in the South Harghita Mountains, Romania. Földtani Közlöny 136: 249-284.

Pop E. 1960. Mlaștinile de turbă din RPR. Editura Academiei Republicii Populare România, București.

Pop E. 1962. Problema vechimii tinovului Mohos de langa Tusnad-Bai. Studia Scientia Cercetari Biologia 13(1): 7-21, Cluj-Napoca.

Pop E., Diaconeasa B. 1967. Analiza palinologica a turbei din tinovul Mohos (Tusnad). Contributii Botanice: 297-303.

Szálai I. 1943. A Hargita két tözeglápjának virágporelemzése, Acta Bot. Szeged. II: 63-102. 
Székely Z. 1980. Archaeological Considerations on the Bronze Age Settlement of Peteni, Covasna county. Archaeological Materials and Researches, Tulcea, pp. 129-134.

Székely Z. 1998. Bradut, Covasna county, in the Chronicle of Archaeological Researches - the 1997 Campaign, Calarasi, pp. 9 - 10.

Tanţău I. 2003. Recherches pollenanalytiques dans les Carpates Orientales (Roumanie). Histoires de la végétation et de l'impact humain. Thèse de doctorat, Université Aix - Marseille III et Université Babes-Bolyai, Cluj - Napoca.

Tanţău I., Reille M., de Beaulieu J.L., Farcas S., Goslar T., Paterne M. 2003. Vegetation history in the eastern Romanian Carpathians: pollen analysis of two sequences from the Mohoş crater. Vegetation History and Archaeobotany 12: 113-125.

Tanţău I. 2006. Histoire de la vegetation tardiglaciare et holocène dans les Carpates Orientales (Romanie). Presa Universitara Clujeana. Cluj-Napoca.

Tanţău I., Reille M., Beaulieu J.L. de, Fărcaş S. 2006. Late Glacial and Holocene vegetation history in the southern part of Transylvania (Romania): pollen analysis of two sequences from Avrig. Journal of Quaternary Science 21: 49-61.

Tanţău I., Reille M., Beaulieu J.L. de, Fărcaş S., Brewer S. 2009. Holocene vegetation history in Romanian Subcarpathians. Quaternary Research 72: 164-173.

Tanţău I., Feurdean A., Beaulieu J.L. de, Reille M., Fărcaş S. 2011. Holocene vegetation history in the upper forest belt of the Eastern Romanian Carpathians. Palaeogeography, Palaeoclimatology, Palaeoecology 309: 281-290. 